\title{
HUBUNGAN SIKAP PEDULI LINGKUNGAN HIDUP SERTA PERILAKU HIDUP BERSIH DAN SEHAT DENGAN PRESTASI BELAJAR MAHASISWA
}

\author{
Ermina Sari ${ }^{1)}$ Romeka Ria ${ }^{2)}$ \\ Pendidikan Biologi FKIP Universitas Lancang Kuning \\ Email $^{1)}$ : Erminasari@unilak.ac.id \\ Email $^{2)}$ : romekaria10@gmail.com
}

\begin{abstract}
ABSTRAK: Penelitian ini bertujuan untuk mengetahui korelasi antara sikap peduli lingkungan serta perilaku hidup bersih dan sehat dengan prestasi belajar mahasiswa 2015 mata kuliah Ilmu Pengetahuan Lingkungan di Prodi Pendidikan Biologi FKIP UNILAK. Penelitian ini dilaksanakan pada bulan Mei 2018. Penelitian ini merupakan penelitian korelasional dan populasi pada penelitian ini adalah seluruh mahasiswa semester 5. Sampel yang diambil sebanyak 86 mahasiswa dengan teknik total sampling. Teknik pengumpulan data menggunakan dokumentasi dan kuesioner. Teknik analisis data yang digunakan adalah pearson product moment. Berdasarkan analisis data yang diperoleh nilai $\mathrm{r}^{2}$ sikap peduli lingkungan terhadap prestasi belajar 0,082 dengan presentase sebesar $8,24 \%$, nilai $\mathrm{r}^{2}$ perilaku hidup bersih dan sehat terhadap prestasi belajar 0,067 dengan presentase sebesar $6,7 \%$ dan nilai koefisien korelasi ganda $F_{h}(5,583)>F_{t}$ $(3,11)$, maka tolak $\mathrm{H}_{0}$ yang berarti terdapat korelasi signifikan antara hubungan sikap peduli lingkungan serta perilaku hidup bersih dan sehat dengan prestasi belajar mahasiswa 2015 mata kuliah Ilmu Pengetahuan Lingkungan di Prodi Pendidikan Biologi FKIP UNILAK.

Kata Kunci: Sikap Peduli Lingkungan, Perilaku Hidup Bersih dan Sehat, Prestasi Belajar
\end{abstract}

ABSTRACT : This study purposed to determine the correlation environmental caring attitude, clean and healthy behavior with the 2015 students achievement of environmental science subject on Biology Education Student's FKIP UNILAK. This research was conducted on May 2018. This research was correlational research and population which the object were all students in fifth semester. Samples taken as many as 86 students by total sampling technique. Data collected method is using documentation and questionnaires. subsequently, data analysis method which used in this research is the pearson product moment. Based on the analysis obtained $r^{2}$ value of enviromental care attitude towards learning achievement 0,082 with a percentage of $8,24 \%$, the value of $r^{2}$ clean and healthy behavior towards learning achievement 0,067 with a percentage of 6,7\%, and multiple correlation coefficient values $F_{h}(5,583)>F_{t}(3,11)$, then reject $H_{0}$, which means there is a significant correlation between the relationship of environmental caring attitude, clean and healthy behavior with the 2015 students achievement of environmental science subject on Biology Education Student's FKIP UNILAK.

Keywords: Environmental caring attitude, clean and healthy living behavior, the achievement of studying 


\section{PENDAHULUAN}

Menurut Soedarto

(2013)

lingkungan dalam pengertian umum adalah semua faktor dan keadaan yang berada di luar tubuh yang mempengaruhi perkembangan dan pertumbuhan organisme atau komunitas organisme. Lingkungan hidup adalah kesatuan ruang dengan benda, daya keadaan dan makhluk hidup termasuk manusia dan perilakunya yang mempengaruhi kelangsungan dan kesejahteraan manusia dan makhluk hidup lainnya.

Perilaku hidup bersih dan sehat (PHBS) merupakan hal penting yang harus dimiliki anak dari orang tua sejak kecil. Berdasarkan hasil penelitian menunjukkan banyak anak usia dini yang memiliki pengetahuan tentang hidup bersih dan sehat kurang yang berdampak pada perilaku yang salah. Bila pengetahuan mahasiswa baik maka perilaku hidup bersih dan sehat juga baik (Aris, 2015). Kepedulian terhadap perilaku hidup bersih dan sehat berasal dari kesadaran diri sendiri yang dapat membentuk atau membangun suasana dan ruangan yang bersih dan sehat. Dalam menjaga kebersihan mahasiswa juga dapat melakukan hal-hal seperti : berpakaian rapi jika berada di dalam kelas, menjaga kesehatan jasmani, mengatur pola makan yang teratur, dan membuang sampah pada tempatnya. Kekurangan perilaku hidup bersih dan sehat adalah kurang pedulinya terhadap kebersihan lingkungan sekitar, tidak menaati peraturan yang ada, dan kurang pemanfaatan dalam pemakaian alat yang telah disediakan.

Prestasi belajar adalah hasil usaha yang dicapai dengan usaha, sesuatu yang dicapai tidak dengan usaha bukanlah suatu prestasi. Prestasi adalah bukti keberhasilan usaha yang dicapai (Sumantri, 2010). Penguasaan terhadap suatu tugas, keterampilan, sikap, nilai dan apresiasi yang diperlukan untuk keberhasilan dalam kehidupan. Prestasi merupakan suatu prestasi siswa pada standar rendah di tandai oleh pemahaman tentang fakta yang mendasar, sedangkan pada standar yang lebih tinggi siswa dapat menunjukkan pengetahuan yang baik (Yusuf \& Hayat, 2010). 
Hubungan sikap peduli lingkungan hidup serta perilaku hidup sehat sangat berpengaruh dengan lingkungan hidup dalam kehidupan sehari-hari, dimana perilaku ini sangat mempengaruhi kesehatan, kebersihan, dan keamanan di lingkungan sekitar kampus. Agar dapat menjaga lingkungan dengan baik, dapat memenuhi kebutuhan bersama untuk meningkatkan rasa kepedulian terhadap lingkungan. Sikap peduli lingkungan yang bertujuan untuk mewujudkan terbentuknya lingkungan kampus yang berkelanjutan dengan demikian perlu dipahami dan diterapkan.

\section{METODE PENELITIAN}

Penelitian ini menggunakan penelitian deskriptif kuantitatif. Penelitian ini dilakukan untuk mengetahui hubungan antara variabel prediktor yaitu sikap peduli lingkungan (X1), perilaku hidup bersih dan sehat (X2) dan variabel kriteria yaitu prestasi belajar (Y). Kerangka pemikiran sebagai berikut :

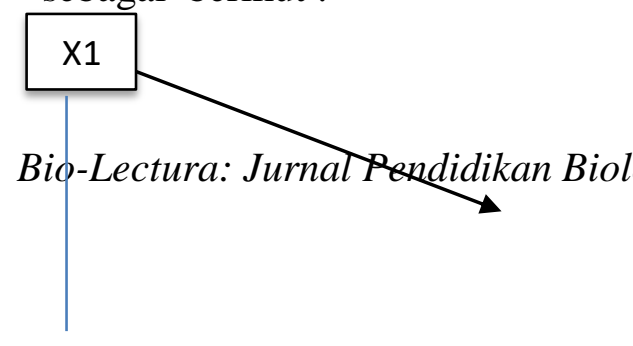

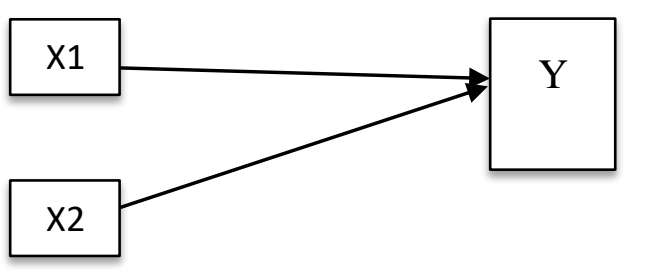

Gambar 1 kerangka pemikiran penelitian

(Sumber : Sugiyono, 2015)

Keterangan :

$\mathrm{r}=$ Koefisien Korelasi

$\mathrm{x}_{1}=$ Sikap Peduli Lingkungan

$\mathrm{x}_{2}=$ Perilaku Hidup Bersih dan Sehat

$\mathrm{Y}=$ Prestasi Belajar

Penelitian ini dilaksanakan pada bulan Mei Tahun 2018 di Fakultas Keguruan dan Ilmu Pendidikan Prodi Pendidikan Biologi Universitas Lancang Kuning J1. Yos Sudarso Km.8 Rumbai Pekanbaru 2017/2018.

Sampel adalah sebagian atau wakil dari populasi yang diteliti Arikunto (2011). Teknik pengambilan sampel dari penelitian ini menggunakan total sampling.

Instrumen penelitian adalah alat atau fasilitas yang digunakan oleh peneliti untuk mengumpulkan data agar pekerjaan lebih mudah dan hasilnya lebih baik, dalam arti lebih cermat, lengkap dan sistematis 
sehingga lebih mudah diolah (Arikunto, 2011). Instrumen yang akan di gunakan pada penelitian ini yaitu berupa angket. Angket disini digunakan untuk memperoleh data mengenai dukungan mahasiswa dan prestasi belajar.

Teknik pengumpulan data yang digunakan dalam penelitian ini yaitu angket dan dokumentasi.

Angket yaitu suatu teknik pengumpulan data dengan menggunakan seperangkat daftar pertanyaan yang telah disusun dan kemudian disebarkan kepada responden untuk memperoleh data yang diperlukan. Kusioner adalah sejumlah pertanyaan tertulis yang digunakan untuk memperoleh informasi dari responden dalam arti laporan tentang pribadinya, atau halhal yang ia ketahui. Kemudian dokumentasi adalah suatu cara yang digunakan untuk mengumpulkan data yang ditunjukan untuk memperoleh penjelasan melelaui sumber-sumber dokumen(Arikunto, 2010).

\section{HASIL DAN PEMBAHASAN}

Penelitian yang dilakukan di Prodi Pendidikan Biologi FKIP Universitas Lancang Kuning tentang hubungan antara sikap peduli lingkungan hidup dan perilaku hidup bersih dan sehat dengan prestasi belajar mahasiswa mata kuliah ilmu pengetahuan lingkungan angkatan 2015 dengan jumlah responden sebanyak $\quad 86 \quad$ siswa.

Tabel 26

Rekapitulasi Hasil Uji Normalitas Populasi

\begin{tabular}{|c|c|c|c|c|c|}
\hline No & Varian Data & $\begin{array}{c}\text { Asymp.Sig. } \\
(2 \text {-tailed })\end{array}$ & $\alpha$ & Keputusan & Kesimpulan \\
\hline 1 & Sikap Peduli Lingkungan & 0,402 & 0,05 & Terima $\mathrm{H}_{0}$ & Normal \\
\hline 2 & Perilaku Hidup Bersih dan Sehat & 0,651 & 0,05 & Terima $\mathrm{H}_{0}$ & Normal \\
\hline 3 & Prestasi Belajar & 0,115 & 0,05 & Terima $\mathrm{H}_{0}$ & Normal \\
\hline
\end{tabular}

Berdasarkan Tabel 26 di atas dapat dilihat bahwa Asymp. Sig. (2tailed)sikap peduli lingkungan pada output Kolmogorov Smirnov adalah 0,402> 0,05. Asymp. Sig. (2- tailed)perilaku hidup bersih dan sehat pada output Kolmogorov Smirnov adalah 0,651>0,05. Asymp. Sig. (2-tailed)prestasi belajar pada outputKolmogorov Smirnov adalah 
0,115> 0,05. Ini menunjukkan bahwa terima $\mathrm{H}_{0}$ yang artinya data berasal dari populasi yang berdistribusi normal.

a) Hasil analisis sikap peduli lingkungan $\left(\mathrm{X}_{1}\right) \quad$ terhadap prestasi belajar(Y) dapat dilihat pada tabel berikut ini: Analisis korelasi sikap peduli lingkungan terhadap prestasi belajar

Hasil analisis sikap peduli lingkungan $\left(\mathrm{X}_{1}\right)$ terhadap prestasi belajar(Y) dapat dilihat pada tabel berikut ini:

Tabel 27

Korelasi Sikap Peduli Lingkungan terhadap Prestasi Belajar

\begin{tabular}{|c|c|c|c|}
\hline Variabel & $\mathrm{R}$ & $\mathrm{r}^{2}$ & $\begin{array}{c}\text { Sig. (2- } \\
\text { tailed) }\end{array}$ \\
\hline $\begin{array}{c}\mathrm{X}_{1} \\
\text { terhadap } \\
\mathrm{Y}\end{array}$ & 0,287 & 0.082 & 0.007 \\
\hline
\end{tabular}

Berdasarkan Tabel 27 di atas, diperoleh korelasi sikap peduli lingkungan terhadap prestasi belajar diperoleh nilai koefisien korelasi $\left(\mathrm{r}_{\mathrm{x}_{1} \mathrm{y}}\right) \quad 0,287>0,209$ pada taraf signifikan $0,007<0,05$ berarti tolak $\mathrm{H}_{0}$ dan $\mathrm{H}_{1}$ diterima dengan $8,24 \%$. Hal ini berarti terdapat hubungan positif hubungan antara sikap peduli lingkungan dengan prestasi belajar IPL mahasiswa searah. Semakin tinggi sikap peduli lingkungan pada mahasiswa maka akan semakin tinggi prestasi belajar mahasiswa pada mata kuliah Ilmu Pengetahuan Lingkungan (IPL). Interpretasi koefisien korelasi nilai $\mathrm{r}$ berkisaran antara $0,20-0,399$. Ini menunjukkan bahwa korelasi antara sikap peduli lingkungan terhadap prestasi belajar mahasiswa pada mata kuliah Ilmu Pengetahuan Lingkungan (IPL)termasuk kategori rendah. Korelasi antara sikap peduli lingkungan terhadap prestasi belajar mahasiswa pada mata kuliah Ilmu Pengetahuan Lingkungan (IPL)dapat dilihat pada gambar berikut: 


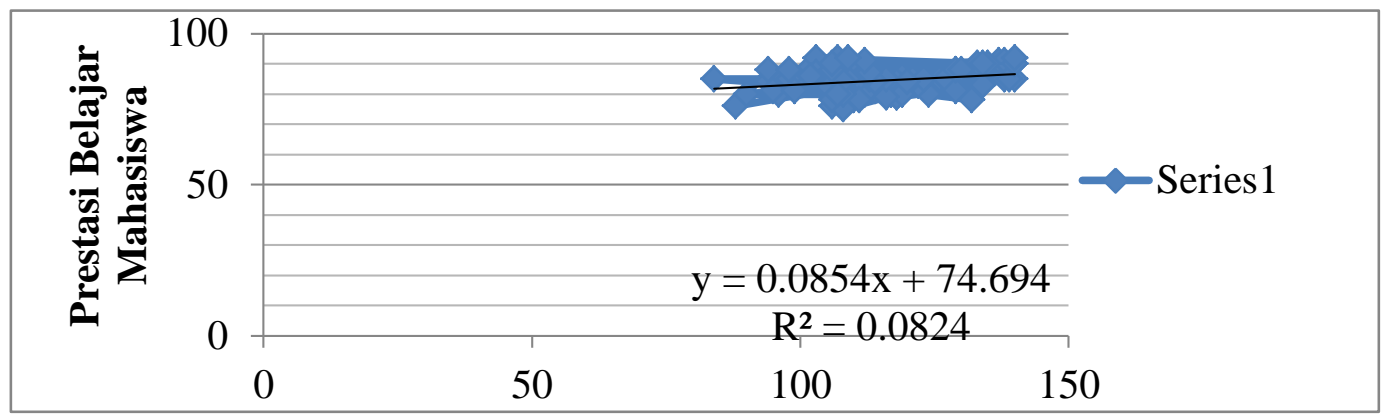

Gambar 4 Scatter Plot Korelasi Sikap Peduli Lingkungan terhadap Prestasi Belajar Mahasiswa Gambar

a) Analisis korelasi perilaku hidup bersih dan sehat terhadap prestasi belajar mahasiswa

Hasil analisis perilaku hidup bersih dan sehat $\left(\mathrm{X}_{2}\right)$ terhadap prestasi belajar mahasiswa (Y) dapat dilihat pada tabel berikut:

Tabel 28

Korelasi terhadapperilaku hidup bersih dan sehat terhadap prestasi belajar mahasiswa

\begin{tabular}{|c|c|c|c|}
\hline Variabel & $\mathrm{R}$ & $\mathrm{r}^{2}$ & $\begin{array}{c}\text { Sig. } \\
(2- \\
\text { tailed })\end{array}$ \\
\hline $\begin{array}{c}\mathrm{X}_{2} \\
\text { terhadap } \\
\mathrm{Y}\end{array}$ & 0,259 & 0,067 & 0,016 \\
\hline \multicolumn{5}{|c|}{ Berdasarkan } & \multicolumn{2}{|c|}{ Tabel 28} & di atas,
\end{tabular}

diperoleh korelasi perilaku hidup bersih dan sehat terhadap prestasi belajar mahasiswa memberikan nilai koefisien korelasi $\left(\mathrm{r}_{\mathrm{x}_{2} \mathrm{y}}\right)$ sebesar 0,259>0,209 dengan taraf signifikan $0,016<0,05$ berarti tolak $\mathrm{H}_{0}$. Hal ini berarti terdapat korelasi searah antara perilaku hidup bersih dan sehat terhadap prestasi belajar mahasiswa. Interpretasi koefisien korelasi nilai $\mathrm{r}$ berkisaran antara 0,20-0,399. Ini menunjukkan bahwa korelasi antara perilaku hidup bersih dan sehat terhadap prestasi belajar mahasiswatermasuk kategori rendah. Korelasi antaraperilaku hidup bersih dan sehat terhadap prestasi belajar mahasiswa dapat dilihat pada gambar berikut: 


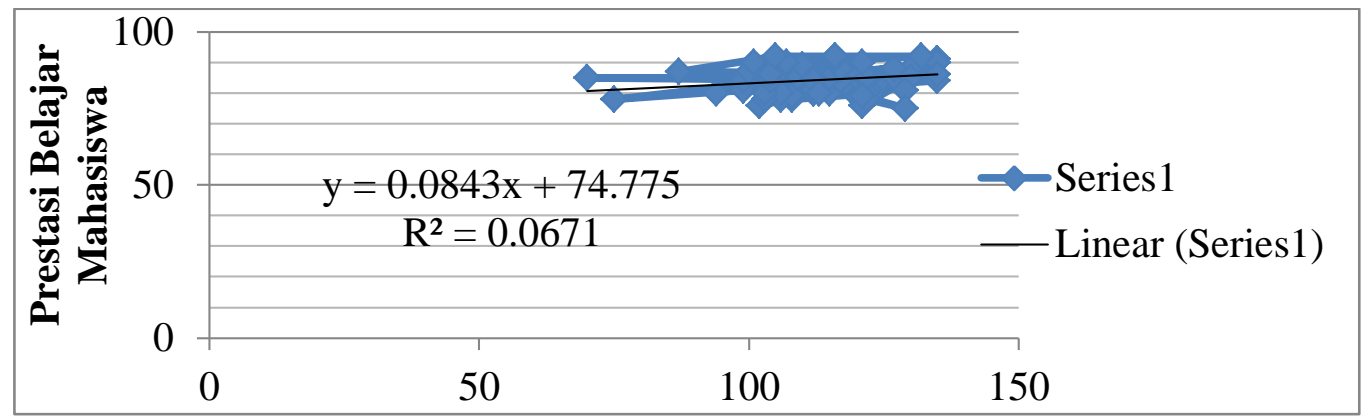

Gambar 5 Scatter Plot Korelasi Perilaku Hidup Bersih dan Sehat terhadap

Prestasi Belajar Mahasiswa

a) Analisis korelasi regresi ganda antara sikap peduli lingkungan dan perilaku hidup bersih dan sehat terhadap prestasi belajar mahasiswa

Hasil analisis korelasi antara sikap peduli lingkungan $\left(\mathrm{X}_{1}\right)$ dan perilaku hidup bersih dan sehat $\left(\mathrm{X}_{2}\right)$ terhadap prestasi belajar mahasiswa (Y)dapat dilihat pada tabel berikut:

\section{Tabel 29}

Korelasi Regresi Ganda antara Sikap Lingkungan dan Perilaku Hidup Bersih dan Sehat terhadap Prestasi Belajar Mahasiswa

\begin{tabular}{|c|c|c|c|}
\hline Variabel & $\mathrm{R}$ & $\begin{array}{c}\text { Sig. (2- } \\
\text { tailed) }\end{array}$ & $\mathrm{F}$ \\
\hline $\begin{array}{c}\mathrm{X}_{1} \text { dan } \\
\mathrm{X}_{2} \\
\text { terhadap } \\
\mathrm{Y}\end{array}$ & 0,344 & 0,005 & 5,583 \\
\hline
\end{tabular}

Berdasarkan Tabel 29 di atas, korelasi antara sikap peduli lingkungan dan perilaku hidup bersih dan sehat terhadap prestasi belajar mahasiswa diperoleh nilai $r_{\text {hitung }}$ koefisien korelasi (R) sebesar 0,344>

0,209 nilai $r_{\text {tabel }}$ dengan taraf signifikan $0,005<0,05$ berarti tolak $\mathrm{H}_{0}$. Hal ini berarti terdapat korelasi positif antara sikap peduli lingkungan dan perilaku hidup bersih dan sehat terhadap prestasi belajar mahasiswa. Tanda (+) menunjukkan korelasi searah hubungan antara sikap peduli lingkungan dan perilaku hidup bersih dan sehat terhadap prestasi belajar mahasiswa. Interpretasi koefisien korelasi nilai $r$ berkisaran antara 0,20-0,399. Ini menunjukkan bahwa korelasi antara sikap peduli lingkungan dan perilaku hidup bersih dan sehat terhadap prestasi belajar mahasiswa termasuk kategori rendah.

Berdasarkan data yang telah dianalisis diperoleh rerata sikap peduli lingkungan skornya 4,26 termasuk kategori sangat tinggi 
dengan persentase sebesar $85,28 \%$. yang dihasilkan dari proses Prestasi belajar yang dihasilkan dari pembalajaran ilmu pengetahuan proses pembalajaran ilmu lingkungan dengan rerata $84,5 \%$ pengetahuan lingkungan dengan menunjukkan kategori baik .Hal ini rerata $84,5 \%$ menunjukkan kategori baik. Hal ini menunjukkan bahwa terdapat hubungan positif antara sikap peduli lingkungan dengan prestasi belajar. Hal ini menunjukkan bahwa sikap perduli lingkungan sebagian besar mahasiswa telah memiliki pengetahuan lingkungan hidup, sehingga menjaga kelestarian lingkungan merupakan kewajiban setiap manusia. Untuk mewujudkan tindakan kepedulian lingkungan hidup yang menjadi suatu kebutuhan bagi setiap mahasiswa. Menurut Fauziet al. (2015) menyatakan bahwa pembentukan tentang lingkungan hidup sejak dini secara terprogram dan berkelanjutan pada saat akan tercipta yang perduli terhadap lingkungan. Berdasarkan data yang dianalisis diperoleh nilai koefisien korelasi $(\mathrm{R})$ sebesar nilai koefisien korelasi $\mathrm{R}=0,344>\mathrm{r}_{\mathrm{t} \text { abel }}=$ berarti terdapat hubungan positif antara sikap peduli lingkungan dan perilaku hidup bersih dan sehat dengan prestasi belajar mahasiswa pada mata kuliah Ilmu Pengetahuan Lingkungan (IPL). Tanda (+) menunjukkan korelasi searah hubungan antara sikap peduli lingkungan dan perilaku hidup bersih dan sehat terhadap prestasi belajar mahasiswa. Semakin baik sikap peduli lingkungan dan perilaku hidup bersih dan sehat maka akan semakin baik pula prestasi belajar. Setelah itu dilakukan uji $\mathrm{F}$ diperoleh $\mathrm{F}_{\text {hitung }}=5,583$ dan nilai $\mathrm{F}_{\text {tabel }}=3,11$, maka $F_{h}(5,583)>F_{t}(3,11)$ sehingga sikap peduli lingkungan dan perilaku hidup bersih dan sehat secara bersama-sama dengan prestasi belajar mempunyai korelasi yang signifikan antara faktor sikap peduli lingkungan dan perilaku hidup bersih dan sehat.

0,209 dengan taraf signifikan 0,005< 0,05 berarti tolak $\mathrm{H}_{0}$. Prestasi belajar 
Berdasarkan Tabel 4.5 di atas,

kecerdasan spiritual, motivasi belajar dan sarana prasarana dengan hasil belajar biologi diperoleh nilai rhitung koefisien korelasi (R) sebesar $0,443>0,308$ dengan taraf signifikan $0,042<0,05$ berarti tolak $\mathrm{H}_{0}$ dan $\mathrm{H}_{1}$ diterima. Hal ini berarti terdapat hubungan positif yang artinya terdapat hubungan antara kecerdasan spiritual, motivasi belajar dan sarana prasarana dengan hasil belajar biologi searah. Ini menunjukkan bahwa korelasi antara kecerdasan spiritual, motivasi belajar dan sarana prasarana dengan hasil belajar biologi termasuk kategori sedang.

Berdasarkan nilai koefisien antar variabel $\left(\mathrm{X}_{1}, \mathrm{X}_{2}, \mathrm{X}_{3}\right.$ dan $\left.\mathrm{Y}\right)$ diatas, maka nilai signifikan korelasi antar variabel $\mathrm{X}_{1}, \mathrm{X}_{2}, \mathrm{X}_{3}$ dan $\mathrm{Y}$ adalah sebagai berikut :

$$
\begin{aligned}
& \mathrm{F}=\frac{\mathrm{F}=\mathrm{R}^{2} / \mathrm{k}}{\left(1-\mathrm{R}^{2}\right) /(\mathrm{n}-\mathrm{k}-1)} \\
& \mathrm{F}=3,009
\end{aligned}
$$

Perhitungan di atas diperoleh $\mathrm{F}_{\mathrm{h}}=$ 3,009 kemudian dilihat dengan $\mathrm{F}_{\text {tabel }}$ korelasi antara korelasi antara $\left(\mathrm{F}_{\mathrm{t}}\right)$, dengan $\mathrm{dk}$ pembilang $=\mathrm{k} \mathrm{dk}$ penyebut $=(\mathrm{n}-\mathrm{k}-1)$, maka $\mathrm{F}_{\text {tabel }}=$ 2,86 Dari perhitungan tersebut ternyata $F_{h}>F_{t}(3,009>2,86)$, maka terima $\mathrm{H}_{1}$ yang berarti terdapat hubungan signifikan antara kecerdasan spiritual, motivasi belajar dan sarana prasarana dengan hasil belajar biologi siswa kelas IX SMP Advent Pekanbaru tahun ajaran 2017/2018.

Berdasarkan hasil penelitian yang dilakukan Kecerdasan Spiritual dan Hubungannya dengan Hasil Belajar Setelah melihat secara rinci data hasil analisis skornya kedelapan indikator termasuk ke dalam kategori tinggi dan nilai koefisien korelasi (rx1y) 0,360 >0,308 taraf sig.0,021< 0,05 trima $\mathrm{H} 1$ yang artinya terdapat adanya hubungan yang linier, yang dipengaruhi oleh faktor yaitu seluruh pernyataan indikator menunjukkan ada didalam diri seseorang yang dimana kepercayaan didalam dirinya akan mempengaruhi hasil belajar .

Motivasi Belajar dan Hubungannya dengan Hasil Belajar Setelah melihat secara rinci data hasil analisis skornya keenam 
indikator termasuk ke dalam kategori tinggi dan nilai koefisien korelasi $(\mathrm{rx} 2 \mathrm{y}) \quad 0,310>0,308 \quad$ taraf sig. $0,018<0,05$ trima H1 yang artinya terdapat adanya hubungan yang linier, yang dipengaruhi oleh faktor yaitu dalam situasi sekolah, siswa yang banyak memiliki motif/dorongan yang berhubungan dengan kebutuhan biologis dan pisikologis akan mempengaruhi hasil belajar.

Pemanfaatan Sarana Prasarana Pembelajaran dan Hubungannya dengan Hasil Belajar Setelah melihat secara rinci data hasil analisis skornya kelima indikator termasuk ke dalam kategori tinggi dan nilai koefisien korelasi (rx3y) $0,470>0,308$ taraf sig. $0,048<0,05$ trima H1 yang artinya terdapat adanya hubungan yang linier, yang dipengaruhi oleh faktor yaitu sekolah yang memiliki sarana prasarana yang mendukung dan lengkap dalam proses pembelajaran baik gedung maupun alat-alat pembelajaran akan mempengaruhi hasil belajar peserta didik.

Hubungan Antara Kecerdasan Spiritual, Motivasi Belajar dan
Pemanfaatan Sarana Prasarana Pembelajaran dengan Hasil Belajar Berdasarkan hasil korelasi (R) $0,443>0,308$ dengan taraf sig. $0,042<0,05$ yang termasuk kategori sedang. Terima H1 yang artinya terdapat hubungan positif yang signifikanyang dapat menghasilkan hasil belajar yang optimal dan target pembelajaran tercapai.

\section{KESIMPULAN}

Berdasarkan hasil penelitian dan analisis data dapat disimpulkan bahwa terdapat hubungan positif antara sikap peduli lingkungan dengan prestasi belajar mahasiswa dengan nilair2 sikap peduli lingkungan terhadap prestasi belajar 0,082 dengan presentase sebesar $8,24 \%$, nilai r2 perilaku hidup bersih dan sehat terhadap prestasi belajar 0,067 dengan presentase sebesar $6,7 \%$. Semakin tinggi sikap peduli lingkungan pada mahasiswa maka akan semakin tinggi prestasi belajar mahasiswa pada mata kuliah Ilmu Pengetahuan Lingkungan (IPL) artinya terdapat hubungan positif antara sikap peduli lingkungan dan perilaku hidup bersih dan sehat 
dengan prestasi belajar mahasiswa. Uji nilai signifikan koefisien korelasi ganda Fh $(5,583)>\mathrm{Ft}(3,11)$, maka tolak H0 yang berarti terdapat hubungan yang signifikan dengan kategori rendah antara sikap peduli lingkungan hidup serta perilaku hidup bersih dan sehat dengan prestasi belajar mahasiswa 2015 mata kuliah Ilmu Pengetahuan Lingkungan di prodi pendidikan biologi FKIP UNILAK.

\section{SARAN}

a. Bagi Dosen

Berdasarkan penelitian, semoga lebih semangat danlebih sabar dalam membentuk sikap peduli lingkungan hidup mahasiswa dalam mata kuliah ilmu pengetahuan lingkungan (IPL) dan hidup bersih dan sehat untuk menjadi suri tauladan kepada mahasiswa/i.

b. Bagi Mahasiswa

Sebaiknya lebih menunjukkan dan mengimplementasikan ilmu pengetahuan lingkungan yang mereka pahami dan pelajari pada saat masuk mata kuliah Ilmu Pengetahuan Lingkungan (IPL) dan meningkatkan sikap peduli terhadap lingkungan dan berperilaku hidup bersih dan sehat dimanapun mereka berada baik di lingkungan kampus, rumah, dan kost-kostan serta lingkungan yang lebih luas lagi.

c. Bagi Peneliti

Apabila ada peneliti yang berminat, sebaiknya mengembangkan variabel penelitian yang sudah ada dengan penelitian lanjutan yang lebih detail lagi.

\section{DAFTAR PUSTAKA}

Arikunto, S. (2010). Prosedur Penelitian Suatu Pendekatan Praktik. Rineka Cipta : Jakarta.

Arikunto, S. (2011). Dasar-dasar Evaluasi Pendidikan. Bumi Aksara : Jakarta.

Aris, A. (2015). Hubungan Pengetahuan Orang Tua dengan Perilaku Hidup Bersih dan Sehat. Jurnal Program Studi Ilmu Keperawatan STIKES Muhammadiyah Lamongan. Vol. 07, No.01.

Fauzi, M, I. Muryani, C. \&Santoso, S .(2018). Hubungan Antara PengetahuanLingkungan Hidup dan Prestasi Belajar Geografi Dengan Sikap Peduli Lingkungan Pada Siswa SMA Negeri di Kabupaten 
Karanganyer. Jurnal GeoEco.

Vol. 4, No. 1. Hal. 88-99.

Soedarto. (2013). Lingkungan dan

Kesehatan. Environment And Healt. Sagung Seto : Jakarta.

Sumantri, B. (2010). Pengaruh

Disiplin Belajar Terhadap

Prestasi Belajar Siswa

Kelas XI SMK PGRI 4 Ngawi.

Jurnal Media Prestasi. Vol.

VI. No. 3

Yusuf, S. \&Hayat, B. (2010).

Bencmark Internasiaonal Mutu

Pendidikan. Bumi

Aksara : Jakarta.

Sugiyono. (2015). Statistika Untuk

Penelitian. Alfabeta: Bandung. 